\title{
Case Study: Analysis of the Physical Factors of Palestinian Bioclimate
}

\author{
Jehad M. H. Ighbareyeh, A. Cano-Ortiz, E. Cano \\ Department of Animal and Plant Biology and Ecology, University of Jaen, Jaen, Spain \\ Email: jehadighbareyeh@hotmail.com
}

Received 23 February 2014; revised 21 March 2014; accepted 16 April 2014

Copyright (C) 2014 by authors and Scientific Research Publishing Inc.

This work is licensed under the Creative Commons Attribution International License (CC BY). http://creativecommons.org/licenses/by/4.0/

c) (i) Open Access

\section{Abstract}

This study analyses the physical factors of the Palestinian bioclimate, the mean monthly and annual temperature, mean monthly maximum temperature, and mean monthly minimum temperature using data from six weather stations from the Palestine Meteorological Department, recorded in two periods: The first period from 1969 to 1981, the second period from 1975 to 1995 (more than 32 years). Statistical tests included a bioclimatic analysis of Palestinian meteorological stations for the periods from 1969-1981 and 1975-1995 by using bioclimatic classification of the Earth of Rivas Martinez Salvador, with regard to thermicity index, compensated thermicity index, annual ombrothermic index, and simple continentality index. The bioclimate of Palestineis affected by various factors, such as the Jordanian-Syrian desert, and its natural geography and topography, among others as well as biodiversity. Annual ombrothermic index value ranging between 0.6 to 3.4 and simple continentality index was from 12.4 to 18.1. It is concluded that the occupied Palestinian territories belong to the arid, semiarid, dry, sub-humid and humid ombrotype, and the Inframediterranean, Thermomediterranean and Mesomediterranean bioclimatic belt.

\section{Keywords}

Indices, Biodiversity, Bioclimatology, Ombrotype, Thermotypes

\section{Introduction}

Palestine is the conventional name used to describe the geographic region between the Mediterranean Sea and the Jordan River and various adjoining lands, the Holy Land and the Southern Levant. Palestine has historically been known by other names including Canaan, Syria Palestine, Southern Syria, Jund Filastin and Outremer [1]-[4]. Geomorphological, although it is a comparatively small area, the West Bank is also characterized by a wide variation in topography [5]. The topography of Palestine has several main geographical features that can be eas- 
ily identified on a map of Palestine: the coastal plain, the central highlands/central hill country, the Jordan Rift/Great Rift Valley, the trans-Jordanian highlands/Transjordan, the Jordan River, the Sea of Galilee, the Dead Sea and the Mediterranean Sea (Figure 1).

The mountainous area of the West Bank serves as the main rainfall collection and replenishment zone for the underground water aquifers. The current climate conditions reveal the cascading effect of bioclimate change. The start and duration of the seasons have changed, and this has exposed Gaza to more fragility [6] [7]. In the other side, climate is considered vulnerability as the propensity of people or systems to be harmed by climate hazards in the context of other domains of vulnerability, as well as in relation to response capabilities in both the short-term (coping) and the long-term (adaptation) [8]. Therefore, climate change has lead to the change in the physical factors of the Palestinian bioclimatic, hydrological cycle and other the environment factors.

The main aims of the present study are to contribute to the knowledge of the mean temperature occurring in Palestine over the past few decades at the monthly, seasonal and annual resolution, and to analyze the physical factors of the bioclimate according to data from the Palestinian meteorological stations for several years.

\section{Materials \& Methods}

\subsection{Study Area}

Palestine is located between longitudes $34^{\circ} 15^{\prime}$ and $35^{\circ} 40^{\prime}$ east and between latitudes $29^{\circ} 30^{\prime}$ and $33^{\circ} 15^{\prime}$ north. The geographic location of Palestine plays a major role in affecting the features of its climate and the climate diversity between the southern and northern parts.

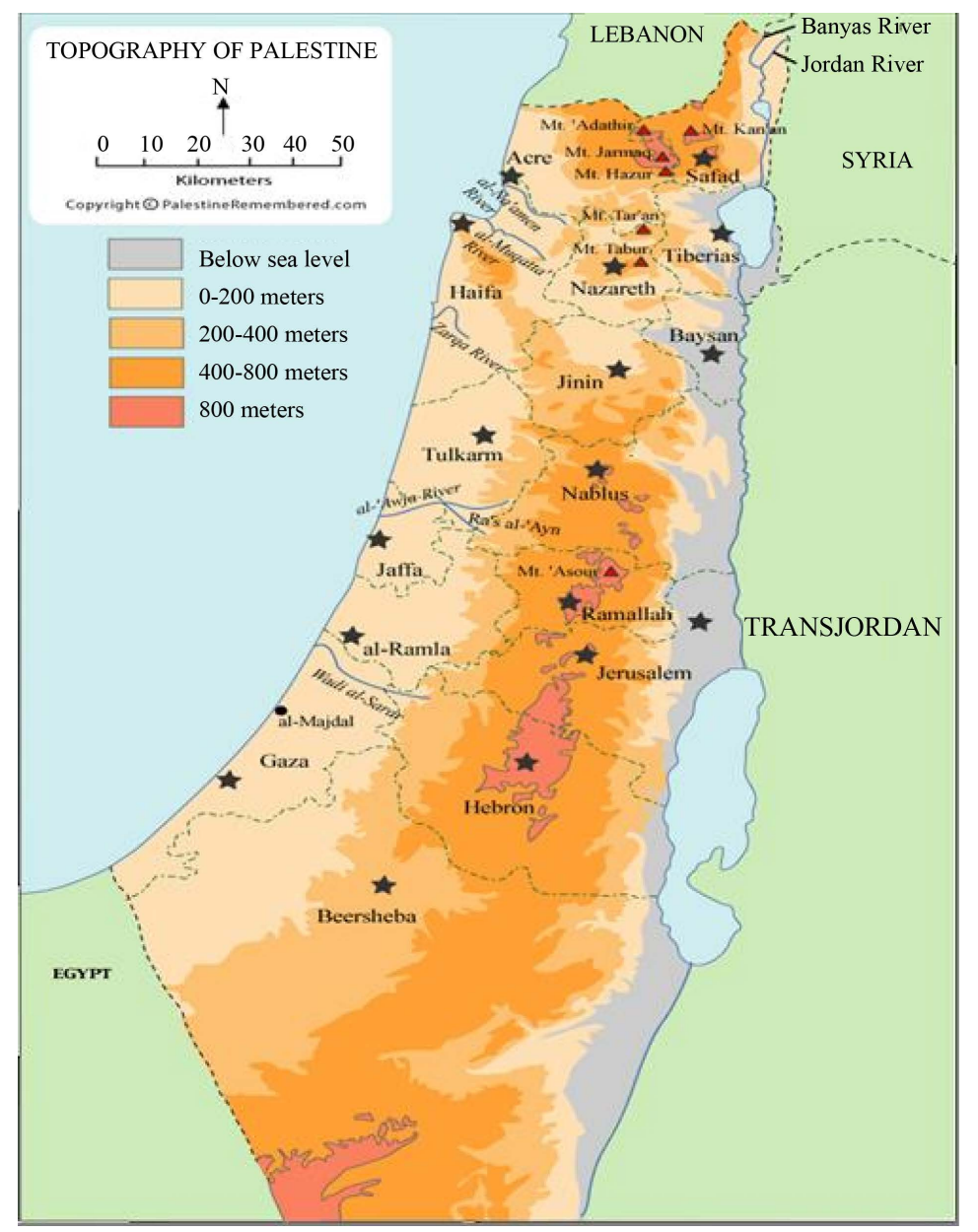

Figure 1. Topography of Palestine. 


\subsection{Climate and Bioclimate Data}

The thermal regime varies significantly with altitude and continentally, especially in winter: from west to east it undergoes a transition from a typical Mediterranean to a continental climate. The winter rain regime has been extensively studied [9]-[13], and changes in annual rainfall patterns [14] [15]. The mountainous regions tend to be windy, very cold and sometimes snowy. The peak of Mount Hermon is covered with snow most of the year [16]. Data were used from the meteorological stations in Palestine (Table 1).

Mean temperature data from six stations with records from 1969 to 1981 and from 1975 to 1995 have been analyzed in this study. A bioclimatic analysis has been made of the data from the Palestinian meteorological stations of the same years ago, so we are dependent in the bioclimatic analysis about used temperature and rain full amount of data for Palestinian Meteorological Stations, elaboration the diagram bioclimatic according the professor Rivas Martinez Salvador in 1996 [17]-[19], and [20]. An analysis was made of the thermicity index (It), compensated thermicity index (Itc), diurnality index (Id), annual ombrothermic index (Io), simple continentality index (Ic), monthly estival ombrothermic index (Ios1), threemonthly estival ombrothermic index (Ios3), annual ombro evaporation index (Ioe), annual positive temperature (Tp), annual negative temperature (Tn), positive precipitation (Pp), mean monthly temperatures(Tm), mean monthly maximum and minimum temperatures.

\section{Results and Discussion}

\subsection{The First Period from 1969 to 1981}

Table 2 shows the sign and magnitude of trends, as well as the statistical significance for each of the six sites analyzed for bioclimatic belts and annual ombrothermic index. Table 3 shows the number of weather stations with bioclimatic factors physicals for Palestine provided by the Palestinian meteorological stations for the years in the study. These tables reveal a clear tendency towards climate change in Palestine during the study period in the six stations in the various years (with regard to thermicity index, compensated thermicity index, mean temperature of the annual warmest month, mean monthly temperatures). Figure 2 shows that the analysis of physical factors, and the climate of Palestine and the Palestinian territories belongs to the humid, sub-humid and arid ombrotype.

Tm: mean monthly temperatures, (It) thermicity index, (Itc) compensated thermicity index, (Io) annual ombrothermic index, (Ic) simple continentality index, (Twm) mean temperature of the warmest monthly, (Tcm) mean temperature of the coldest monthly, (Ios1) monthly estival ombrothermic index, (Ios2, Iso3) bimonthly, three monthly estival ombrothermic index, (Tm. M. Max) mean monthly maximum temperatures, (Tm. M. Min) mean monthly minimum temperatures. Table 2 shows the bioclimatic analysis according to the data from the Palestinian meteorological stations in two stages.

Nevertheless, in the first period, we can observe that the precipitation amounts differ from one station to another, with the highest proportion in Hebron and Al-Arroub (located in Hebron) $596 \mathrm{~mm}$ and $633 \mathrm{~mm}$ respectively, and the lowest at the Jericho station. The mean temperature of the warmest month in Jericho is about $22^{\circ} \mathrm{C}$; Al-Fará (in Nablus) is about $19.5^{\circ} \mathrm{C}$, while the lowest mean monthly temperature is in Hebron with $4.0^{\circ} \mathrm{C}$. The monthly, biomonthly, three monthly estival ombrothermic indexes were equal to zero for most stations except Hebron and

Table 1. Coordinates of meteorological stations Palestinian.

\begin{tabular}{|c|c|c|c|}
\hline Station & Latitude (North) & Longitude (East) & Elevation $\mathrm{m}$ \\
\hline Jenin & $32.28 \mathrm{~N}$ & $35.18 \mathrm{E}$ & 178 \\
\hline Gaza & $31.30 \mathrm{~N}$ & $34.27 \mathrm{E}$ & 13 \\
\hline Tulkarem & $32.19 \mathrm{~N}$ & $35.01 \mathrm{E}$ & 83 \\
\hline Nablus & $32.13 \mathrm{~N}$ & $35.15 \mathrm{E}$ & 570 \\
\hline Al-Arroub & $31.50 \mathrm{~N}$ & $35.09 \mathrm{E}$ & 887 \\
\hline Ramallah & $31.89 \mathrm{~N}$ & $35.21 \mathrm{E}$ & 856 \\
\hline Jericho & $31.51 \mathrm{~N}$ & $35.27 \mathrm{E}$ & -260 \\
\hline Hebron & $31.32 \mathrm{E}$ & $35.06 \mathrm{E}$ & 1005 \\
\hline
\end{tabular}


Table 2. Bioclimatic analysis of Palestinian meteorological stations in the periods 1969-1981 and 1975 to 1995 (32 years).

\begin{tabular}{cccccccccccc}
\hline Station & Tm & P. mm & Io & Ic & It/Itc & Twm. & Tcm. & Tm. M. Max. & $\begin{array}{c}\text { Tm. M. } \\
\text { Min. }\end{array}$ & Iso3 \\
\hline Jericho & 22.4 & 166 & 0.6 & 13.0 & $528 / 528$ & 22.0 & 7.4 & 34.8 & 15.3 & 0.0 \\
Hebron & 15.5 & 596 & 3.2 & 15.0 & $297 / 297$ & 10.2 & 4.0 & 19.9 & 11.1 & 0.01 \\
BeitGad & 21.3 & 414 & 1.6 & 15.0 & $466 / 466$ & 18.2 & 7.1 & 26.7 & 13.5 & 0.0 \\
Al- Fara & 23.6 & 225 & 0.8 & 17.0 & $524 / 524$ & 19.5 & 9.3 & 30.2 & 17.0 & 0.0 \\
Gaza & 19.8 & 446 & 1.9 & 12.4 & $467 / 467$ & 17.5 & 9.4 & 23.6 & 16.1 & 0.0 \\
Al-Arroub & 17.1 & 633 & 3.1 & 16.7 & $428 / 428$ & 21.3 & 4.4 & 22.9 & 10.4 & 0.0 \\
Ramallah & 17.2 & 636 & 3.4 & 14.9 & $306 / 306$ & 10.5 & 4.4 & 21.1 & 31.1 & 0.01 \\
Jericho & 22.7 & 168 & 0.6 & 13.0 & $496 / 496$ & 19.1 & 7.8 & 29.6 & 15.7 & 0.0 \\
Hebron & 15.5 & 628 & 3.4 & 15.3 & $294 / 294$ & 10.0 & 4.0 & 19.6 & 11.2 & 0.1 \\
Gaza & 19.9 & 441.3 & 1.85 & 13.6 & $457 / 457$ & 18.0 & 7.8 & 25.8 & 13.9 & 0.0 \\
Nablus & 17.2 & 664 & 3.1 & 13.4 & $378 / 378$ & 13.0 & 7.2 & 21.6 & 13.6 & 0.0 \\
Tulkarem & 20.1 & 652 & 2.7 & 12.8 & $468 / 468$ & 18.8 & 7.9 & 25.7 & 13.9 & 0.0 \\
\hline
\end{tabular}

Table 3. Bioclimatic belts and ombrotype in Palestine.Simple continentality index (Ic), ombrothermic index (Io) and compensated thermicity index (It/Itc).

\begin{tabular}{|c|c|c|c|c|c|}
\hline Provinces & Termotype & Omprotype & Ic & Io & It/Itc \\
\hline Ramallah & Lower mesomediterranean & Upper dry & 16.4 & $3.1-3.4$ & $306 / 306$ \\
\hline Nablus & Upper thermomediterranean & Upper dry & 18.1 & $3.0-3.1$ & $378 / 378$ \\
\hline Jericho & Lower inframediterranean & Upper arid & 13 & $0.6-1.0$ & $528 / 528$ \\
\hline Hebron & Lower mesomediterranean & Upper dry & 17.6 & $3.1-3.4$ & 297/297 \\
\hline Tulkarem & Lower inframediterranean & Lower dry & 16.0 & $2.2-2.7$ & $468 / 468$ \\
\hline Beit gad & Upper inframediterranean & Upper semiarid & 15.0 & 1.6 & $466 / 466$ \\
\hline Al-Arroub & Lower thermomediterranean & Upper dry & 16.7 & 3.1 & $428 / 428$ \\
\hline Al-Fara & Lower inframediterranean & Upper arid & 17 & 0.8 & $524 / 524$ \\
\hline Gaza & Upper Inframediterranean & Upper semiarid & 12.4 & 1.9 & $467 / 467$ \\
\hline
\end{tabular}

Jenin, which have a very low three monthly estival ombrothermic index of about 0.01 . This factor appears similar to another recent study [21], because there are no found rainfalls and compensations in these areas.

\subsection{The Second Period from 1975 to 1995}

The series indicate that the mean monthly temperatures over the period $1975-1995$ is between $15.5^{\circ} \mathrm{C}$ in $\mathrm{Hebron}$ station, and $22.7^{\circ} \mathrm{C}$ in Jericho station, while in 1968-1981 the mean monthly temperature is between $15.5^{\circ} \mathrm{C}$ in Hebron station and $22.4^{\circ} \mathrm{C}$ in Jericho station. The annual mean rainfall was between $160 \mathrm{~mm}$ at Jericho station, and $664 \mathrm{~mm}$ at Nablus station. The rainfall year 1991-1992 has the highest quantity rainfall throughout the past thirty years, the quantity of rainfall ranges between $352 \mathrm{~mm}$ in Jericho station with an increase of $192 \mathrm{~mm}$ over the normal average, and $1388 \mathrm{~mm}$ in Nablus station with an increase of $720 \mathrm{~mm}$ over the normal average, the mean monthly maximum temperature is between $19.9^{\circ} \mathrm{C}$ in Hebron station, and 34.8 in Jericho station, while it is 23.6 in 


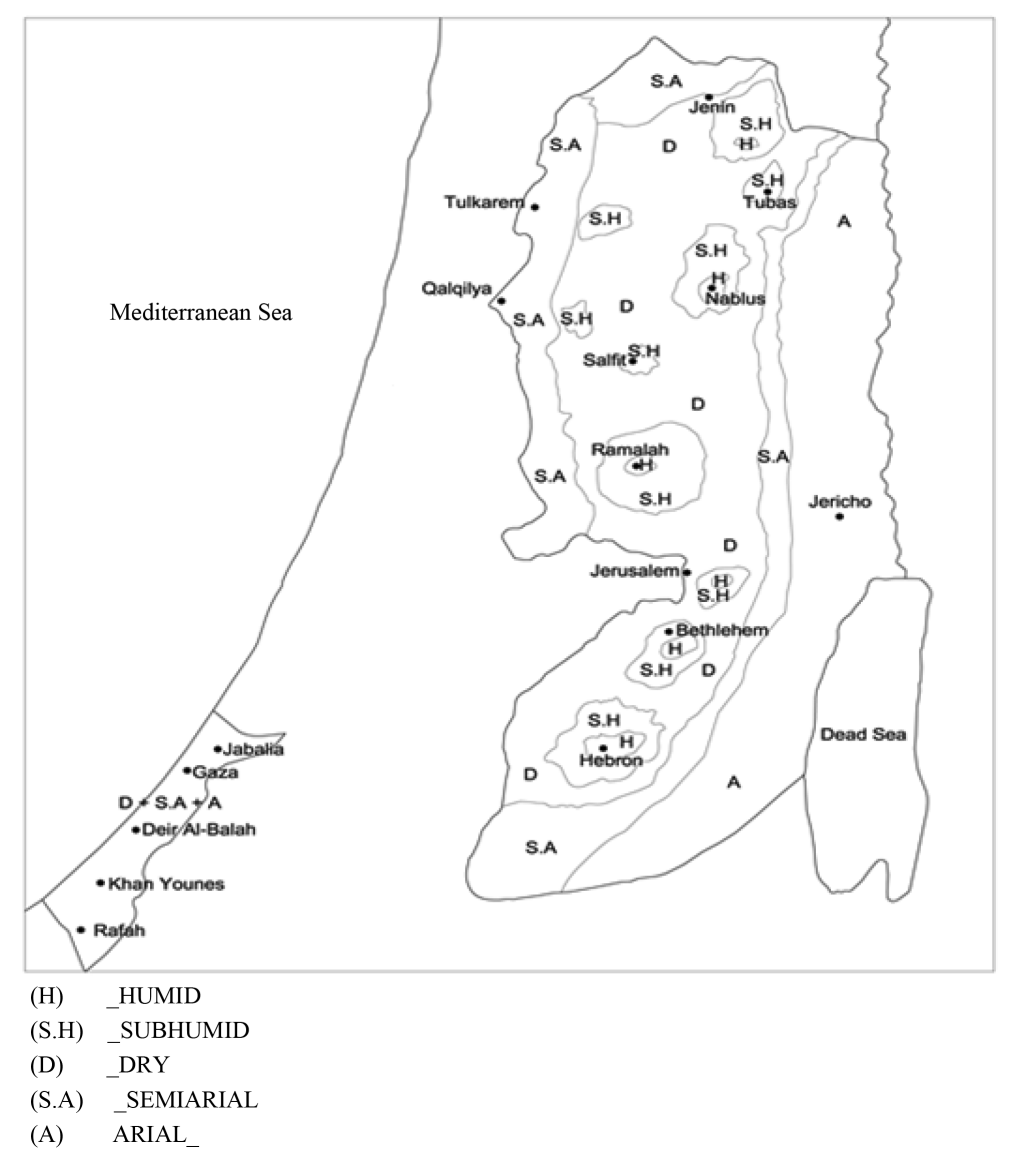

Figure 2. Ombrotype of Palestine.

Gaza station (1969-1981). In general, the lowest mean monthly temperature was recorded in the Hebron station and the highest in Jericho. Time series data indicated that the mean monthly minimum temperature over the period 1975-1995 was between $11.2^{\circ} \mathrm{C}$ in Hebron and $15.7^{\circ} \mathrm{C}$ in Jericho. There is a difference in temperature between the previous stages in the regions and by Israeli research demonstrating that the average temperatures in the eastern Mediterranean have increased steadily over the last 100 years [22]. A different approach for explaining climatic in the southern Israel was presented by Alpert and Mandel [23]. Ben-Gai et al. [24] also mentioned the different approaches regarding the role of the sensible heat flux in explaining regional climate change and climatology.

\subsection{Analyses the Physical Factors of the Bioclimate}

However, there are some studies suggested that precipitation levels may decrease for Israeli-Palestinian region [11] [25] [26]. Annual precipitation rates are deemed likely to fall in the eastern Mediterranean decreasing $10 \%$ by 2020 and 20\% by 2050-with an increased risk of summer drought [27]. In Table 2, the thermicity index and compensated thermicity index was highest in Al-Fara (524/524), Jericho (528/528), and lowest in Ramallah and Hebron (about, 306/306, 294/294 respectively for the period 1975 to 1995 only). The annual ombrothermic index was highest in Hebron and Ramallah with 3.4 and lowest in Jericho, Gaza and Beit Gad village in Jenin, with values of 0.6, 1.85 and 1.6 respectively. The simple continentality index was found to be highest in Nablus and Hebron and lowest in Jericho and Tulkarem in the studies periods. The amount of rain falling and the rest of factors in Palestinian areas during the periods (1969-1981 and 1975-1995) results in (Table 2), show the differences in temperature between the stations during the periods previous; such as the mean monthly temperatures are the highest in Jericho, with $22.7^{\circ} \mathrm{C}$, Tulkarem with $20.1^{\circ} \mathrm{C}$, and Al-Fará in Nablus with $23.6^{\circ} \mathrm{C}$, while the lowest, in Ramallah, Nablus and Hebron are $17.2^{\circ} \mathrm{C}$ and $15.5^{\circ} \mathrm{C}$ respectively. The mean monthly rainfall is highest in the province of Nablus (664 mm), Tulkarem (652 mm) and Ramallah. Through the results in this paper, we find that 
there is a big difference in the physical factors of the bioclimate in Palestine between the study periods. In Jericho area, we see that the (It/Itc) is about (528/528); Io is 0.6; mean temperature of the warmest monthly (Twm) had sought $22.0^{\circ} \mathrm{C}$ at the first period, while in the second period (496/496) and (Twm) is to $19.1^{\circ} \mathrm{C}$; and in Gaza compensated thermicity index are (467/467); (Io) annual ombrothermic index is 1.9; mean monthly Maximum temperature is $23.6^{\circ} \mathrm{C}$; (Ic) simple continentality index is 12.4 ; (Twm) is 17.5 and precipitation is $446 \mathrm{~mm}$ at the first period. While in the second period in Gaza station, (It/Itc) are (457/457); (Ic) is 13.6; mean monthly minimum temperature is $13.9^{\circ} \mathrm{C}$ while $16.1^{\circ} \mathrm{C}$ at the first stage; meanmonthly maximum temperture is $25.8^{\circ} \mathrm{C}$ and precipitation is $441.3 \mathrm{~mm}$, there is a difference between the factors bioclimatic, station to another in Palestine and the rest of the information shown in (Table 2). It means that there is a difference in these factors between the three periods due to the difference in biodiversity, mountain range extending from north to south and running parallel to the coast, amount of water that falls, natural geography and topography, the level of elevation above sea level and other factors, therefore, these factors affect the biology of plants, bioclimatology, climatology, and on the economy in Palestine especially in the agricultural sector in current and future [28], and the environment in general such as land degradation, and its driving forces are climate and bioclimate factors variations and human activities. Land condition becomes the key to interaction between biophysical and human system in the desertification processes [29]. This interaction is complex to the extent that the land management practices affect the condition of the land. Environment is influenced by climatic and bioclimate factors. Conversely, the bioclimate restricts the range of land management practices that can be sustainably employed [30]. In the other side, the need to deal and cope with climatological hazards is commonly understood in intergovernmental and aid agency for as a purely technical matter and the creation of the Palestinian society to these climatic changes in all respects and until now climate and bioclimatology changes have not been securitized [31] [32].

The Occupied Palestinian Territory (OPT), with a total area of $6023 \mathrm{~km}^{2}$, is located in South-West Asia in the heart of the Middle East. It consists of two physically separated land masses: the West Bank and the Gaza Strip with a total area of $5661 \mathrm{~km}^{2}$ and $362 \mathrm{~km}^{2}$ respectively [33]. It represents approximately $21 \%$ of the territory of historic Palestine $\left(27,000 \mathrm{~km}^{2}\right)$. The bioclimatic belts in the occupied Palestinian territories belong to the inframediterranean (45\% - 50\%), thermomediterranean (35\% - 40\%), mesomediterranean (less than 5\% - 10\%), and we believed that found regions belong to the supramediterranean but it's less than $1 \%$ of the total area of the West Bank. The territories of Jericho and Gaza present a tropical xeric and desert bioclimate, and upper inframediterraneanthermotype; and an arid, semi-arid and dry ombrotype. According to the analysis of physical factors, ombrotype of Palestine have the following bioclimatic.

According to (Table 2) and (Figure 3), we can observe that there is a difference in the Palestinian bioclimatic belts or thermotype among different regions; Ramallah and Hebron stations have the highest value of annual ombrothermic index with 3.2 to 3.4, as they have low temperatures and high precipitation. The thermicity index and compensated thermicity index was highest in Jericho (528/528) and Al-Fara (524/524), and lowest in Hebron and Ramallah, as shown in Table 3. The simple continentality index was highest in Nablus (Al-fara) and Hebron station and lowest in Gaza and Jericho. In general, the occupied Palestinian territories belong to the arid, semiarid, dry, sub-humid and humid ombrotype. In place with semi-desert and dry climates olive cultivation is located, while the cereal is developed in sub-humid and humid. In Table 3, the Jericho region belongs to the classification established as desert and semi-desert, with an upper arid ombrotype and a low lower inframediterranean thermo type. As the precipitation is about $200 \mathrm{~mm}$ to $300 \mathrm{~mm}$, the ombrothermic index is about 0.6 to 1.0. It has high temperatures due to its location below sea level at -260 meters, to the change in topography and other factors. The provinces of Ramallah, Hebron, Tulkarem and Nablus belong to the upper dry and lower dry, especially the mountain regions or highlands.

Moreover, the climate of Palestine is traditionally described as "Mediterranean", characterized by winter rain and summer drought. However, there is a great diversity in this climate, which is modified locally by latitude and altitude. This is especially apparent in the West Bank. Climate zones range from extremely arid to humid according to the De Martonne aridity index classification for arid area. The total area of extremely arid, hyper arid and arid climates is $2461 \mathrm{~km}^{2}$ which comprises about $44 \%$ of the land area of the West Bank; the area of the semi-arid part is $1682 \mathrm{~km}^{2}$ (about 30\%); the sub humid area is $1435 \mathrm{~km}^{2}$ (25\%) and the humid area is $67 \mathrm{~km}^{2}(1 \%)$ [5] [34]. We indicated the absence of the political control over the land by the Palestinians due to the severe measures of the Israeli Occupation confiscation of land and water, rapid growth of the population and the improper distribution of the population in arid, semi-arid and desert lands [35]. 


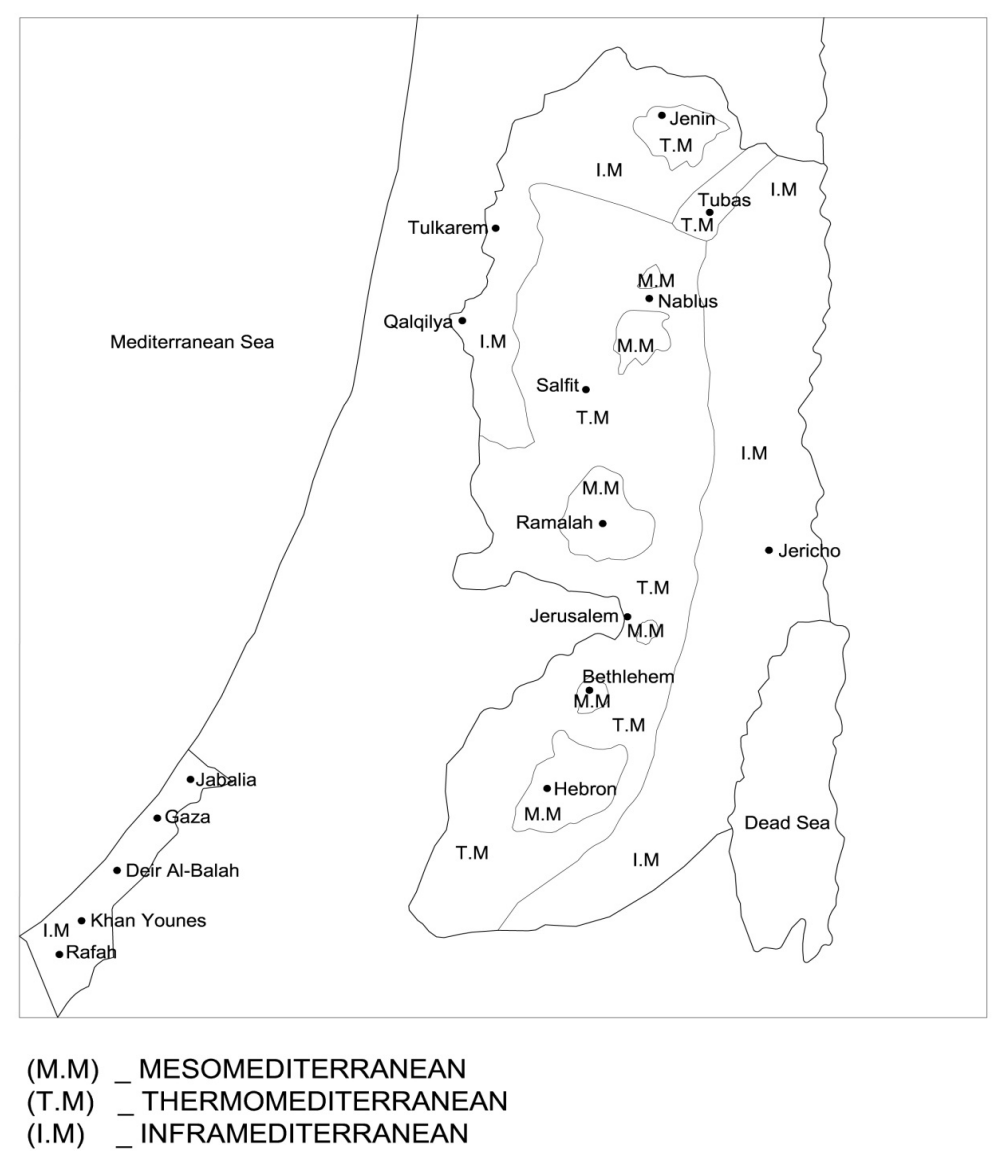

Figure 3. Thermotypes of Palestine.

\section{Conclusions}

The bioclimate of Palestine can be classified as Mediterranean pluviseasonal-oceanic, Mediterranean xericoceanic, Mediterranean desertic-oceanic, while the latitudinal belt is subtropical, within the territorial of a tropical character. Continentally it is oceanic-low semi-continental, oceanic-low euoceanic, oceanic-low semi-hyper oceanic and oceanic-low sub-continental. In addition, the thermotype ranges from inframediterranean to mesomediterranean (inframediterranean, thermomediterranean, mesomediterranean).

The physical factors of the Palestinian bioclimate are affected by several factors: 1) The Mountain range extending from north to south and running parallel to the coast; b) The Sinai and the North African desert; c) The Jordanian-Syrian desert; d) The terrain and the extent of the rise or fall in sea level; e) Natural geography and topography. Palestine is located within a radius of 500 kilometers from the island of Cyprus, and as we move further from the center of this circle, the low air deflects or moves towards the north, and thus the low air moving away from Palestine leads to a decrease in the proportion of rain-fed on Palestine. This also plays an important role in influencing the physical factors of bioclimate and climate and then bioclimate influence on plant communities and biological resources.

\section{References}

[1] Pappe, I. (2006) A History of Modern Palestine: One Land, Two Peoples. Cambridge University Press, Cambridge.

[2] Pappe, I. (2004) A History of Modern Palestine, One Land, Two Peoples, Cambridge University Press, Cambridge. (Printed in the United States of America)

[3] Ahlstrom, G.W. (1993) The History of Ancient Palestine. Augsburg Fortress Publishers, Minneapolis.

[4] Carl, S.E. (2001) Philistines. In: Metzger, B.M. and Coogan, M.D., Eds., The Oxford Guide to People and Places of the Bible, Oxford University Press, Oxford. 
[5] Ali, M.A. (2000) Managing Fragile Ecosystems: Combating Desertification and Drought, Localizing Agenda 21 in Palestine, 103-118. The Applied Research Institute, Jerusalem.

[6] Mimi, Z., Ziara, M. and Nigim, H. (2003) Water Conservation and Its Perception in Palestine: A Case Study. Water and Environmental Management Journal, 17, 152-156. http://dx.doi.org/10.1111/j.1747-6593.2003.tb00453.x

[7] Mimi, Z. and Assi, A. (2009) Intrinsic Vulnerability, Hazard and Risk Mapping for Karst Aquifers: A Case Study. Journal of Hydrology, 364, 298-310. http://dx.doi.org/10.1016/j.jhydrol.2008.11.008

[8] Mason, M., Ziad, M. and Zeitoun, M. (2010) Climate Change Adaptation Strategy and Programme of Action for the Palestinian Authority. United Nations Development Program, Programme of Assistance to the Palestinian People, Jerusalem. http://www.undp.ps/en/newsroom/publications.html

[9] Alpert, P. and Reisin, T. (1986) An Early Winter Polar Airmass Penetration to the Eastern Mediterranean. Monthly Weather Review, 114, 1411-1418. http://dx.doi.org/10.1175/1520-0493(1986)114<1411:AEWPAM>2.0.CO;2

[10] Alpert, P., Neeman, B.U. and Shay-El, Y. (1990) Climatological Analysis of Mediterranean Cyclones Using ECMWF Data. Tellus, 42A, 65-77. http://dx.doi.org/10.1034/j.1600-0870.1990.00007.X

[11] Alpert, P., Krichak, S.O., Shafir, H., Haim, D. and Osetinsky, I. (2008) Climatic Trends to Extremes Employing Regional Modeling and Statistical Interpretation over the E. Mediterranean. Global Planetary Change, 63, 163-170. http://dx.doi.org/10.1016/j.gloplacha.2008.03.003

[12] Samuels, R., Rimmer, A. and Alpert, P. (2009) Effect of Extreme Rainfall Events on the Water Resources of the Jordan River. Journal of Hydrology, 375, 513-523.

[13] Samuels, R., Rimmer, A., Hartmann, A., Krichak, S. and Alpert, P. (2010) Climate Change Impacts on Jordan River Flow: Downscaling Application from a Regional Climate Model. Journal of Hydrometeorology, 11, 860-879. http://dx.doi.org/10.1175/2010JHM1177.1

[14] Ben-Gai, T., Bitan, A., Manes, S. and Alpert, P. (1994) Long-Term Changes in Annual Rainfall Patterns in Southern Israel. Theoretical and Applied Climatology, 49, 59-67. http://dx.doi.org/10.1007/BF00868190

[15] Bitan, A. and Saaroni, H. (1990) The Unusual Rain Spells of October 1985. Israel Journal of Earth Sciences, 39, 3346.

[16] Goldreich, Y. (2003) The Climate of Israel: Observation, Research and Application. Springer, Berlin.

[17] Rivas-Martinez, S. (1996) Clasificación bioclimática de la Tierra. Folia Bot. Matritensis, 16, 1-20.

[18] Rivas-Martínez, S. (2007) Mapa de series, geoseries y geopermaseries de vegetación de España. Memoria del mapa de vegetación potencial de España. Parte 1. Itinera Geobotánica, 17, 1-222.

[19] Rivas-Martinez, S. (2008) Global Bioclimatic. http://www.globalbioclimatics.org

[20] Rivas-Martínez S., Rivas-Sáenz, S. and Penas, A. (2011) Worldwide Bioclimatic Classification System. Global Geobotany, 1, 1-634.

[21] Jehad, M., Ighbareyeh, H., Cano-Ortiz, A. and Cano, E. (2014) Biological and Bioclimatic Basis to Optimize Plant Production: Increased Economic Areas of Palestine. Agricultural Science Research Journal, 4, 10-20. http://www.resjournals.com

[22] Krichak, S.O., Alpert, P., Bassat, K. and Kunin, P. (2007) The Surface Climatology of the Eastern Mediterranean Region Obtained in a Three-Member Ensemble Climate Change Simulation Experiment. Advances in Geosciences, 12, 67-80. www.adv-geosci.net/12/67/2007/

[23] Alpert, P. and Mandel, M. (1986) Wind Variability-An Indicators for a Mesoclimatic Change in Israel. Journal of Climate and Applied Meteorology, 25, 1568-1576. http://dx.doi.org/10.1175/1520-0450(1986)025<1568:WVIFAM>2.0.CO;2

[24] Ben-Gai, T., Bitan, A., Manes, A. and Alpert, P. (1993) Long-Term Change in October Rainfall Patterns in Southern Israel. Theoretical and Applied Climatology, 46, 209-217. http://dx.doi.org/10.1007/BF00865708

[25] Black, E. (2009) The Impact of Climate Change on Daily Precipitation Statistics in Jordan and Israel. Atmospheric Science Letters, 10, 192-200. http://dx.doi.org/10.1002/asl.233

[26] Sowers, J., Vengosh, A. and Erika, W. (2011) Climate Change, Water Resources and the Politics of Adaptation in the Middle East and North Africa. Climatic Change, 104, 599-627. http://dx.doi.org/10.1007/s10584-010-9835-4

[27] Mason, M., Mimi, Z. and Zeitoun, M. (2009) Climate Change Adaptation Strategy and Program of Action for the Palestinian National Authority: Climate Change Adaptation Strategy for the Occupied Palestinian Territory. The Program Was Initiated by Environmental Quality Authority (EQA) and Financed by UNDP/PAPP.

[28] Jonathan, L. and Kirshen, P. (2009) Water Allocation, Climate Change, and Sustainable Water Use in Israel/Palestine: The Palestinian Position. Water International, 34, 189-203.

[29] del Barrio, G., Puigdefabregas, J., Sanjuan, M.E., Stellmes, M. and Ruiz, A. (2010) Assessment and Monitoring of 
Land Condition in the Iberian Peninsula, 1989-2000. Remote Sensing of Environment, 114, 1817-1832. http://dx.doi.org/10.1016/j.rse.2010.03.009

[30] Henry, B., McKeon, G.M., Syktus, J., Carter, J.O., Day, K.A. and Rayner, D.P. (2007) Climate Variability, Climate Change and Land Degradation. In: Sivakumar, M.V.K. and Ndiang'ui, N., Eds., Climate and Land Degradation, Springer, Berlin \& Heidelberg, 205-221.

[31] Mason, M., Zeitoun, M. and Ziad, M. (2012) Compounding Vulnerability: Impacts of Climate Change on Palestinians in Gaza and the West Bank. Journal of Palestine Studies, 41, 1-16.

[32] Mason, M. (2013) Climate Change, Securitization and the Israeli-Palestinian Conflict. The Geographical Journal, Published Online.

[33] Isaac, J., AKhair, A., Hilal, J., Ghattas, R. and Hardee, P. (2011) Status of the Environment in the Occupied Palestinian Territory, a Human Rights-Based Approach. The Applied Research Institute Jerusalem (ARIJ), Bethlehem.

[34] Dudeen, B.A. (2007) Land Degradation in Palestine: Main Factors, Recent States and Trends, Recommended Actions, Jerusalem: Land Research Centre. FAO, 1984. Crop Water Requirements, Paper No. 24, Rome.

[35] EQA and UNCCD (2012) The National Strategy, Action Programme and Integrated Financing Strategy to Combat Decertification in the Occupied Palestinian Territory. Environment Quality Authority, United Nations Convention to Combat Desertification, Ramallah. 
Scientific Research Publishing (SCIRP) is one of the largest Open Access journal publishers. It is currently publishing more than 200 open access, online, peer-reviewed journals covering a wide range of academic disciplines. SCIRP serves the worldwide academic communities and contributes to the progress and application of science with its publication.

Other selected journals from SCIRP are listed as below. Submit your manuscript to us via either submit@scirp.org or Online Submission Portal.
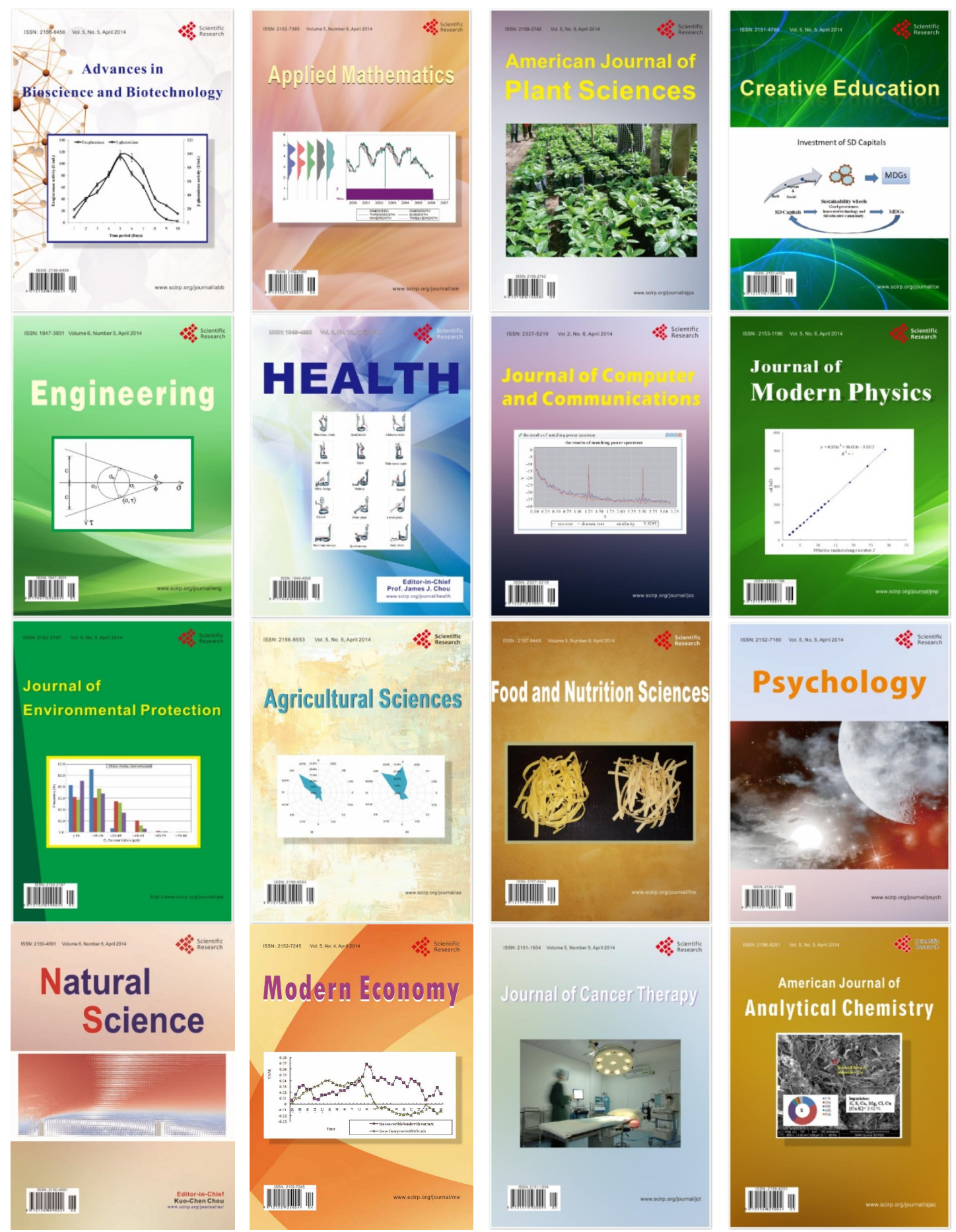